\title{
ANALIZA ZAŁOŻEŃ KONCEPCJI INTEGRACJI TRANSPORTU ZBIOROWEGO Z INDYWIDUALNYM
}

\begin{abstract}
Głównym celem integracji transportu indywidualnego i zbiorowego jest skłonienie podróżnych do odbywania podróży multimodalnych. Polega ona na wykorzystaniu w mniej zaludnionej i skomunikowanej strefie podmiejskiej samochodu, a w mieście - komunikacji zbiorowej. Podróż taka obywa się etapami, przy wykorzystaniu różnorodnych form przemieszczania, od podróży pieszych i rowerowych, poprzez komunikację miejską: metro, tramwaje, trolejbusy, aż po własny samochód. Na szczególną uwagę w tej mierze zasługują koncepcje: Park \& Ride oraz Bike \& Ride ${ }^{2}$.

Wyniki obserwacji prowadzonych przez autorkę wskazują na to, że wiedza znacznej grupy Polaków na temat koncepcji integracji transportu zbiorowego i indywidualnego w mieście jest znikoma lub po prostu tej wiedzy brak. Dlatego dobrym pomysłem wydaje się zaprezentowanie i omówienie rozwiązań, takich jak: Park \& Ride, Bike \& Ride, Kiss \& Ride, bardziej szczegółowo.
\end{abstract}

Celem artykułu jest próba zaprezentowania wybranych koncepcji integracji transportu zbiorowego i indywidualnego, które wykorzystywane są przede wszystkim w dobrze rozwiniętych miastach Europy Zachodniej - w Pradze, Wiedniu, Kopenhadze czy Berlinie. Postawiony cel determinuje wybór metody badawczej, jaką jest metoda analizy i krytyki literatury przedmiotu.

Znajomość opisywanych koncepcji jest szczególnie istotna dla osób zajmujących się logistyką miejską i pracujących nad rozwiązaniami dotyczącymi rozwiązania problemu kongestii transportowej i nadmiernego zatłoczenia miast. W artykule opisano istotę zintegrowanego systemu podróży miejskiej i bardziej szczegółowo omówiono istotę koncepcji: Park \& Ride, Bike \& Ride, Kiss \& Ride.

Słowa kluczowe: podróż multimodalna, zintegrowany system podróży miejskiej, Park \& Ride, Bike \& Ride, Kiss \& Ride, transport miejski

\section{WPROWADZENIE}

Wraz z rozwojem cywilizacji i szybkim poziomem urbanizacji ośrodków miejskich mieszkańcy stanęli przed problemami związanymi ze sprawną komunikacją. Przemieszczanie się osób jest powodem kongestii transportowej, nadmiernego hałasu, zanieczyszczeń powietrza i obniżenia jakości życia mieszkańców. Współczesne miasta zmieniają się coraz szybciej, a podróż po lokalnych drogach publicznych i sieciach tranzytowych staje się jednym z głównych utrudnień w mieście. Tworzące się zatory drogowe, wzrost zanieczyszczenia powietrza czy dłuższy czas podróży powodują niezadowolenie wśród ludności. Mieszkańcy muszą coraz częściej polegać na zintegrowanych systemach transportu, aby móc podróżować efektywnie

\footnotetext{
${ }^{1}$ Mgr Paulina Bełch, Katedra Systemów Zarządzania i Logistyki, Wydział Zarządzania, Politechnika Rzeszowska, Al. Powstańców Warszawy 8, 35-959 Rzeszów, tel. (17) 86518 02, e-mail: pbelch @ prz.edu.pl

${ }^{2}$ W. Starowicz, Koncepcja rozwoju transportu publicznego w miastach. Ekspertyza, Politechnika Krakowska, Zakład Organizacji i Ekonomiki Transportu, Kraków 2010, s. 77,

http://rzecznik.dlalodzi.info/pliki/rzecznik/pisma/starowicz.pdf (dostęp: 15.11.2014).
} 
i tanio pomiędzy domem, pracą i miejscami użyteczności publicznej. Integracja transportu zbiorowego z indywidualnym jest integralną częścią logistyki miejskiej.

Celem artykułu jest próba zaprezentowania wybranych założeń koncepcji integracji transportu zbiorowego z indywidualnym. Postawiony cel determinuje wybór metody badawczej, jaką jest metoda analizy i krytyki literatury przedmiotu.

\section{ISTOTA ZINTEGROWANEGO SYSTEMU PODRÓŻY MIEJSKIEJ}

Jak twierdzi Jacek Szołtysek, zadanie integrowania przepływów należy do podstawowych obszarów zainteresowania logistyki miejskiej. Zwraca on uwagę na możliwości, jakie stwarza multimodalizm, który często nazywany jest filozofią transportu. Jego zdaniem transport multimodalny oznacza wewnętrznie zintegrowany przewóz przy użyciu co najmniej dwóch rodzajów transportu, przy czym każdy z nich realizuje swoje zadania podporządkowane potrzebom procesów transportowych ${ }^{3}$. Integracja wymusza na miastach organizację multimodalnych systemów transportowych, które wywodzą się z koncepcji podziału miasta na strefy komunikacyjne. W każdej strefie transport indywidualny, zbiorowy czy pieszy ma przypisaną inną rangę ${ }^{4}$. Przewozy multimodalne uważane są za korzystną formę współdziałania środków komunikacji zbiorowej i indywidualnej w systemie transportowym miasta ${ }^{5}$.

Zdaniem Olgierda Wyszomirskiego integrację transportu miejskiego należy rozpatrywać z punktu widzenia podmiotów i przedmiotów integracji. Biorąc pod uwagę pierwszy aspekt, powinien on obejmować wszystkie podmioty, które mogą uczestniczyć we wszystkich poziomach integracji. Do grupy tych podmiotów należy zaliczyć między innymít

- użytkowników transportu zbiorowego i indywidualnego;

- przedsiębiorstwa transportu zbiorowego skoncentrowane na obsłudze przewozów miejskich;

- przedsiębiorstwa transportu zbiorowego skoncentrowane na obsłudze przewozów regionalnych, krajowych i międzynarodowych;

- $\quad$ władze samorządu terytorialnego;

- wyspecjalizowanych i wyodrębnionych organizatorów transportu zbiorowego o zasięgu regionalnym, krajowym i międzynarodowym.

W czasach, kiedy dynamicznie wzrasta rola podróży intermodalnych, bardzo ważne wydaje się budowanie węzłów przesiadkowych wewnątrz gałęzi transportu drogowego (autobustramwaj, transport miejski - transport zamiejski, Park \& Ride, Bike \& Ride, Kiss \& Ride), a także między różnymi gałęziami transportu - zwłaszcza autobus/tramwaj-kolej. W wielu wypadkach pasażer jest zmuszony do przechodzenia przez jezdnie, co znacznie zwiększa stopień zagrożenia dla jego zdrowia lub życia. Aby zwiększyć bezpieczeństwo zarówno komunikacyjne, jak i osobiste, należy dążyć do zmniejszania czasu przebywania na węźle i skracania dróg przejścia pomiędzy przystankami lub peronami ${ }^{7}$.

\footnotetext{
${ }^{3}$ J. Szołtysek, Podstawy logistyki miejskiej, Wydawnictwo Akademii Ekonomicznej w Katowicach, Katowice 2007, s. 77-78.

${ }^{4}$ Idem, Logistyczne aspekty zarzadzania prze ptywami osób i tadunków w miastach, Wydawnictwo Akademii Ekonomicznej w Katowicach, Katowice 2009, s. 169.

${ }^{5}$ Idem, Podstawy logistyki..., s. 78-80.

${ }^{6}$ O. Wyszomirski, Transport miejski. Ekonomika i organizacja., Wydawnictwo Uniwersytetu Gdańskiego, Gdańsk 2008, s. 252.

${ }^{7}$ W. Starowicz, op. cit., s. 90.
} 
Strategiczne aspekty związane z poziomem integracji transportu indywidualnego z transportem zbiorowym przedstawiono w tabeli 1 .

Tabela 1. Priorytetowe aspekty integracji transportu indywidualnego i zbiorowego z przykładami

\begin{tabular}{|c|c|c|}
\hline \multirow{7}{*}{$\begin{array}{l}\text { Strategiczne } \\
\text { aspekty zwią- } \\
\text { zane z pozio- } \\
\text { mem integracji } \\
\text { transportu } \\
\text { indywidualnego } \\
\text { z transportem } \\
\text { zbiorowym }\end{array}$} & Aspekt & Przykład \\
\hline & $\begin{array}{l}\text { Wspólna infrastruktura umożliwia- } \\
\text { jąca łączenie podróży realizowa- } \\
\text { nych transportem zbiorowym i } \\
\text { transportem indywidualnym }\end{array}$ & $\begin{array}{l}\text { Parkingi dla samochodów i rowerów stano- } \\
\text { wiące element zintegrowanych węzłów prze- } \\
\text { siadkowych }\end{array}$ \\
\hline & $\begin{array}{l}\text { Wspólne usługi umożliwiające } \\
\text { łączenie podróży realizowanych } \\
\text { transportem zbiorowym i transpor- } \\
\text { tem indywidualnym }\end{array}$ & $\begin{array}{l}\text { Wypożyczalnie samochodów i rowerów, } \\
\text { między innymi umożliwiające oddanie środka } \\
\text { transportu w innym miejscu niż to, w którym } \\
\text { nastąpiło wypożyczenie }\end{array}$ \\
\hline & $\begin{array}{l}\text { Oferowanie dodatkowych usług w } \\
\text { zintegrowanych węzłach przesiad- } \\
\text { kowych właścicielom samochodów } \\
\text { i rowerów }\end{array}$ & $\begin{array}{l}\text { Serwis, czyszczenie i konserwacja samocho- } \\
\text { dów i rowerów }\end{array}$ \\
\hline & $\begin{array}{l}\text { Umożliwienie przewożenia rowe- } \\
\text { rów za pomocą środków transportu } \\
\text { zbiorowego }\end{array}$ & $\begin{array}{l}\text { W wydzielonych strefach wewnątrz środka } \\
\text { transportu, w specjalnych bagażnikach przy- } \\
\text { stosowanych do przewozu rowerów }\end{array}$ \\
\hline & $\begin{array}{l}\text { Wspólny system informacji, ze } \\
\text { szczególnym uwzględnieniem } \\
\text { bieżącej informacji o warunkach } \\
\text { podróży w ramach systemu trans- } \\
\text { portu miejskiego i możliwości } \\
\text { korzystania z zintegrowanej oferty } \\
\text { transportu zbiorowego i transportu } \\
\text { indywidualnego }\end{array}$ & $\begin{array}{l}\text { Tablice interaktywne wyświetlające godzinę } \\
\text { odjazdu środka transportu, informujące o } \\
\text { opóźnieniach, temperaturze powietrza }\end{array}$ \\
\hline & $\begin{array}{l}\text { Wspólny system zarządzania ru- } \\
\text { chem umożliwiający płynne dosto- } \\
\text { sowania do zmieniającego się } \\
\text { natężenia i kierunków ruchu z } \\
\text { uwzględnieniem określonych prio- } \\
\text { rytetów dla podróży pieszych i } \\
\text { rowerowych oraz realizowanych } \\
\text { transportem zbiorowym }\end{array}$ & $\begin{array}{c}\text { Wykorzystanie Inteligentnych Systemów } \\
\text { Transportowych, zastosowanie tzw. zielonej } \\
\text { fali }\end{array}$ \\
\hline
\end{tabular}

Źródło: opracowanie własne na podstawie: H. Kołodziejski, Perspektywy i kierunki integracji transportu publicznego w Polsce, Kutno 11 kwietnia 2013 r., www.zmp.poznan.pl.

Optymalne osiągnięcie celów integracji transport miejskiego wymaga, aby jej zakres przedmiotowy obejmował następujące sfery ${ }^{8}$ :

- układ linii i rozkłady jazdy;

- $\quad$ taryfy i system biletowy;

- $\quad$ organizacja i regulacja ruchu;

- $\quad$ system opłat za korzystanie z infrastruktury transportowej oraz zasady dostępu do tej infrastruktury;

- $\quad$ standard oferowanych usług i zasady dostępu do rynku;

${ }^{8}$ O. Wyszomirski, op. cit., s. 254. 
- $\quad$ informacja o usługach i ich promocja;

- $\quad$ badania marketingowe i rynkowe;

- dystrybucja usług;

- węzły integracyjne.

Zadaniem programów integracji transportu zbiorowego $\mathrm{z}$ indywidualnym jest przede wszystkim usprawnienie przepływu osób w systemie logistycznym miasta. Ponadto wykorzystanie dalej opisanych koncepcji ma ograniczyć poziom kongestii transportowej, a poprzez to ograniczyć negatywne skutki tego zjawiska na środowisko naturalne czy jakość życia mieszkańców.

\section{KONCEPCJA PARK \& RIDE}

System parkingów skomunikowanych z punktem przesiadkowym, jakim bez wątpienia jest system Park \& Ride, został zapoczątkowany w zachodnich krajach europejskich i w Stanach Zjednoczonych. Powodem wprowadzenia takiej koncepcji był problem nadmiernego zatłoczenia, hałasu, zanieczyszczeń powietrza oraz wibracji szkodliwych dla ludzi i budynków (szczególnie w centrum miasta). Początkowo system ten obejmował miejsca postojowe, które położne były w sąsiedztwie przystanków autobusowych ${ }^{9}$.

Pierwsze parkingi skomunikowane $\mathrm{z}$ punktem przesiadkowym powstały w latach siedemdziesiątych XX wieku. Inwestycje w parkingi typu Park \& Ride w amerykańskich obszarach miejskich zaczęły się w 1970 roku, w odpowiedzi na podnoszenie globalnych cen ropy naftowej i odnowione zainteresowanie transportem zbiorowym. Dlatego rozwiązanie Park \& Ride nie jest pojęciem nowym dla wielu obszarów Ameryki Północnej.

Jak twierdzi Jacek Malasek, koncepcja Park \& Ride ${ }^{10}$ to podstawowy element zintegrowanego systemu komunikacyjnej obsługi aglomeracji. Element ten tworzą parkingi zlokalizowane przy przystankach i stacjach linii komunikacji zbiorowej dowożących podróżnych do centrum miasta. Zadaniem tego rozwiązania jest odciążenie centrum miasta od ruchu samochodów osobowych ${ }^{11}$.

Koncepcja Park \& Ride to program, który ma na celu zachęcenie mieszkańców miast do podróżowania transportem multimodalnym. Po dojechaniu własnym środkiem transportu (najczęściej samochodem) do parkingu można kontynuować podróż środkami komunikacji publicznej ${ }^{12}$.

Parkingi typu Park \& Ride stanowią jeden z kluczowych elementów zintegrowanego systemu obsługi komunikacyjnej miasta. Do podstawowych korzyści wynikających z zastosowania tej koncepcji jest zwolnienie znacznej liczby miejsc parkingowych w centrum miasta.

Poprawa funkcjonowania systemu miejskiego w wyniku wprowadzenia tej koncepcji zależy od stopnia spełnienia następujących warunków ${ }^{13}$ :

- odpowiednia pojemność parkingów;

- $\quad$ właściwy koszt podróży w systemie Park \& Ride;

\footnotetext{
${ }^{9}$ S. Stienstra, Park and Ride, okoliczności sprzyjające, warunki i wymagania w świetle doświadczeń różnych krajów, „Zeszyty Naukowo Techniczne SITK w Krakowie” 2003/106, s. 25.

${ }^{10}$ Inne nazwy spotykane w literaturze i praktyce to: P+R bądź Park-and-ride, w Polsce zaś - Parkuj i jedź

${ }^{11}$ J. Malasek, Obstuga komunikacyjna centrów miast, WKŁ, Warszawa 1981, s. 197.

12 J. Szołtysek, Logistyczne aspekty zarzadzania przeptywami..., s. 170-171.

${ }^{13}$ J. Malasek, op. cit., s. 71.
} 
- $\quad$ dobre powiązanie parkingów z centrum miasta lub aglomeracji za pomocą środków komunikacji zbiorowej;

- $\quad$ stosowna lokalizacja parkingów.

Powszechnie uważa się, że koncepcja Park \& Ride jest idealnym rozwiązaniem dla osób dojeżdżających spoza miasta. Wzrastająca popularność tej koncepcji jest wynikiem rosnących opłat za postój w centrum miasta. W celu optymalizacji kosztów doskonałym pomysłem wydaje się dojazd do przedmieścia i kontynuowanie podróży środkami publicznego transportu zbiorowego ${ }^{14}$. Koncepcja ta prowadzi do redystrybucji ruchu samochodowego, a nie do jego ograniczenia ${ }^{15}$.

Warto zauważyć, że pierwsze parkingi tego typu powstały w Krakowie pod koniec lat dziewięćdziesiątych XX wieku. Jednak ponieważ znajdowały się za blisko centrum, mieszkańcy wykorzystywali je jako parkingi docelowe. W 2003 r. zdecydowano o ich zlikwidowaniu. W listopadzie 2012 r. uruchomione zostały parkingi Park \& Ride „Parkuj i Jedź”, które są częścią systemu Komunikacji Miejskiej w Krakowie. Rozwiązanie to funkcjonuje także w Poznaniu i w Warszawie.

\section{BIKE \& RIDE}

Rower jest uznawany jako indywidualny środek transportu do odbywania krótkich podróży (3-9 km). Poprzez powiazanie go z transportem zbiorowym może również służyć do odbywania dalszych podróży. W sposobie przewozu można wyróżnić cztery formy integracji transportu zbiorowego $\mathrm{z}$ rowerowym ${ }^{16}$ :

- $\quad$ dojazd z domu transportem zbiorowym do miejsca zaparkowania roweru lub parkingu rowerów miejskich i kontynuacja podróży rowerem (Ride \& Bike);

- $\quad$ dojazd rowerem z domu do przystanku komunikacji zbiorowej i kontynuacja podróży transportem zbiorowym (Bike \& Ride);

- $\quad$ dojazd rowerem z domu do przystanku, przewóz roweru transportem zbiorowym i dojazd rowerem do celu podróży;

- $\quad$ dojazd rowerem z domu do przystanku komunikacji zbiorowej, kontynuacja podróży transportem zbiorowym bez roweru i dojazd do celu podróży drugim rowerem (Bike \& Ride \& Bike).

Dzięki prawidłowemu przeprowadzeniu powiązania $\mathrm{z}$ transportem zbiorowym rower może doskonale zwiększyć swój zasięg i umożliwiać dogodne podróżowanie na dużo większych dystansach. Najczęstszymi formami zazębiania się tych dwóch sposobów podróżowania na terenie współczesnych miast są: zintegrowany system Bike \& Ride oraz umożliwienie przewozu rowerów w pojazdach komunikacji zbiorowej ${ }^{17}$.

Jacek Szołtysek definiuje Bike \& Ride jako koncepcję podróżowania po mieście rowerami, które później można zabrać ze sobą do środków transportu publicznego. Niektóre

\footnotetext{
${ }^{14}$ J. Szołtysek, Logistyczne aspekty zarzqdzania przeptywami..., s. 171.

${ }^{15}$ G. Parkhurst, Influence of Bus-Based Park and Ride Facilities on Users Car Traffic, ,Transport Policy” 7/2 (2000), s. 159.

${ }^{16}$ A. Buczyński, S. Kopta, Koncepcja rozwoju sieci tras rowerowych na obszarze Gminy Wołomin na lata 20072013, czerwiec 2008, s. 60, http://www.zm.org.pl.

${ }^{17} \mathrm{http} / / /$ droga.pl/inzynieria-ruchu/komunikacja-publiczna/5546-rower-jako-uzupelnienie-transportuzbiorowego-1-bike-a-ride
} 
miasta oferują nie tylko specjalne wyposażenie środków transportu (autobusów, metra, trolejbusów), ale również możliwość odpłatnego przechowywania rowerów ${ }^{18}$.

Zaletą parkingów Bike \& Ride jest ich modułowość. Na etapie wstępnego projektowania trzeba zabezpieczać powierzchnię niezbędną do zorganizowania parkingu na kilkaset rowerów, ale w początkowej fazie tworzenia można realizować go tylko w części. Poprzez te kroki miasto optymalizuje wydatki w tym zakresie i ponosi koszty proporcjonalne do poziomu popularności systemu w danej lokalizacji. Rowerem służącym do dojazdów do węzła B\&R może być tani i nieatrakcyjny dla złodzieja sprzęt używany, co pozwoli znacznie obniżyć koszty związane z korzystaniem z tego zintegrowanego systemu transportu ${ }^{19}$.

Koncepcja Bike \& Ride to rozwiązanie o znacznie mniejszych wygodach infrastrukturalnych niż Park \& Ride. Rozwiązanie to dobrze sprawdza się w miastach niezbyt rozbudowanych przestrzennie ${ }^{20}$. W krajach europejskich powszechne jest tworzenie parkingów dla rowerów w projektach parkingów przesiadkowych Park \& Ride oraz niezależnych parkingów Bike \& Ride ${ }^{21}$.

W Rzeszowie do października 2014 r. przewóz rowerów środkami zbiorowego transportu publicznego był zabroniony. W Dzienniku Urzędowym Województwa Podkarpackiego 18 września ukazała się nowelizacja uchwały nr LXXIX/1431/2014 Rady Miasta Rzeszowa z 26 sierpnia 2014 r. zmieniająca uchwałę Rady Miasta Rzeszowa w sprawie określenia przepisów porządkowych związanych z przewozem osób i bagażu środkami publicznego transportu zbiorowego ${ }^{22}$.

W świetle tej nowelizacji od października 2014 r. przewóz roweru nie podlega opłacie, lecz „nie może utrudniać przejścia, narażać na szkodę podróżnych lub ich mienie. Jeżeli rower zajmuje miejsce przeznaczone na wózek dziecięcy lub inwalidzki, a w autobusie pojawi się podróżny z takim wózkiem, miejsce to należy niezwłocznie udostępnić, nawet jeżeli wymaga to opuszczenia autobusu. Obowiązkiem rowerzysty jest wsiąść do pojazdu jako ostatni z podróżnych"23.

\section{KISS \& RIDE}

Koncepcja Kiss \& Ride ma na celu zwiększenie bezpieczeństwa, a zarazem zmniejszenie problemów związanych z negatywnymi skutkami kongestii transportowej w pobliżu szkół. Program ten ma na celu zapewnienie bezpiecznego dotarcia do szkół dzieciom $\mathrm{w}$ wieku szkolnym $\mathrm{w}$ systemie multimodalnym. Władze miast ustalają przystanki, na których dyżurują nauczyciele bądź rodzice (ochotnicy) ubrani w odpowiednio oznakowane odblaskowe kamizelki. Dzieci dowożone są do szkół autobusami kursującymi regularnie, bardzo często wydzielonymi pasami ruchu ${ }^{24}$.

\footnotetext{
${ }^{18}$ J. Szołtysek, Podstawy logistyki miejskiej, s. 81.

${ }^{19} \mathrm{http}: / /$ edroga.pl/inzynieria-ruchu/komunikacja-publiczna/5546-rower-jako-uzupelnienie-transportuzbiorowego-1-bike-a-ride (dostęp: 10 grudnia 2014).

${ }^{20}$ M. Szymczak, Logistyka miejska, Wydawnictwo Akademii Ekonomicznej w Poznaniu, Poznań 2008, s. 167.

${ }^{21}$ A. Buczyński, S. Kopta, op. cit., s. 61.

${ }^{22}$ http://www.ztm.erzeszow.pl/Portals/0/DokumentyDoPobrania/LXXIX_1431_2014.pdf.

${ }^{23}$ Ibidem.

${ }^{24}$ J. Szołtysek, Podstawy logistyki miejskiej, s. 81 .
} 
Do warunków, które muszą być spełnione, aby system Kiss \& Ride działał prawidłowo, należą między innymi:

- $\quad$ nadzór zapewniają pracownicy szkoły, bądź rodzice - ochotnicy;

- dzieci wysiadają z prawej strony samochodu;

- kierowcy pozostają w samochodzie, dyżurujący pomagają zamykać drzwi samochodowe;

- $\quad$ samochody odjeżdżają w kolejności, w jakiej przyjechały.

Warunki te mają na celu zwiększenie przepustowości placów, uniknięcie korków oraz przede wszystkim zwiększenie bezpieczeństwa dzieci. Czas postoju na przystanku oznakowanym Kiss \& Ride może trwać od 3-5 minut.

Ponadto koncepcja Kiss \& Ride nie ogranicza się tylko do wysadzania dzieci i młodzieży szkolnej. Pozwala ona na zatrzymanie prywatnego samochodu w celu wysadzenia lub odebrania pasażera na stacji kolei, metra czy też autobusu pospiesznego. Miejsce takiego zatrzymania są oznaczone odpowiednimi znakami drogowymi i jest niezależne od zatrzymywania taksówek czy autobusów ${ }^{25}$.

W listopadzie 2013 r. cztery miejsca postojowe „Pocałuj i jedź” powstały w centrum Krakowa.

\section{ZAKOŃCZENIE}

W wypadku podróży multimodalnych szczególnego znaczenia nabiera rzetelna i łatwo przyswajalna informacja pasażerska. Dostępność do niej powinna być czynnikiem zachęcającym, a nie zniechęcającym do odbywania podróży różnymi środkami transportu publiczne$\mathrm{go}^{26}$.

Znajomość opisywanych koncepcji jest szczególnie istotna dla osób zajmujących się logistyką miejską i pracujących nad rozwiązaniami dotyczącymi rozwiązania problemu kongestii transportowej i nadmiernego zatłoczenia miast. Każda $\mathrm{z}$ omawianych koncepcji usprawniających przepływy osób w miastach oraz integrujących transport publiczny $\mathrm{z}$ indywidualnym ma wady i zalety. Nieodłącznym elementem funkcjonowania każdej z nich jest oprócz infrastruktury, odpowiedniej lokalizacji, integracji taryfowo-biletowej akcja promująca korzystanie z podróży multimodalnych wśród mieszkańców.

\section{LITERATURA}

[1] Buczyński A., Kopta S., Koncepcja rozwoju sieci tras rowerowych na obszarze Gminy Wołomin na lata 2007-2013, czerwiec 2008 [w:] http://www.zm.org.pl (dostęp: 10.11.2014).

[2] http://edroga.pl/inzynieria-ruchu/komunikacja-publiczna/5546-rower-jako uzupelnienietransportu- zbiorowego-1-bike-a-ride (dostęp: 10.11.2014).

[3] http://www.ztm.erzeszow.pl/Portals/0/DokumentyDoPobrania/LXXIX_11_2014.pdf （dostęp:10.11.2014)

[4] Kołodziejski H. Perspektywy i kierunki integracji transportu publicznego $w$ Polsce, Kutno 11 kwietnia 2013 r. [w:] www.zmp.poznan.pl (dostęp:10.11.2014)

[5] Malasek J., Obstuga komunikacyjna centrów miast, WKŁ, Warszawa 1981.

[6] Parkhurst G., Influence of Bus-Based Park and Ride Facilities on Users Car Traffic, „Transport Policy” 2000, vol. 7, nr 2

\footnotetext{
${ }^{25}$ M. Szymczak, op. cit., s. 168

${ }^{26}$ W. Starowicz , op. cit., s. 77.
} 
[7] Starowicz W., Koncepcja rozwoju transportu publicznego w miastach. Ekspertyza, Politechnika Krakowska, Zakład Organizacji i Ekonomiki Transportu, Kraków 2010, s. 77 [w:] http://rzecznik.dlalodzi.info/pliki/rzecznik/pisma/starowicz.pdf (dostęp:10.11.2014)

[8] Stienstra S, Park and Ride, okoliczności sprzyjajace, warunki $i$ wymagania $w$ świetle doświadczeń różnych krajów, Zeszyty Naukowo Techniczne SITK w Krakowie, Zeszyt 106, Kraków 2003.

[9] Szołtysek J., Logistyczne aspekty zarządzania prze pływami osób i ładunków w miastach, Wydawnictwo Akademii Ekonomicznej w Katowicach, Katowice 2009.

[10] Szołtysek J., Podstawy logistyki miejskiej, Wydawnictwo Akademii Ekonomicznej w Katowicach, Katowice 2007.

[11] Szymczak M., Logistyka miejska, Wydawnictwo Akademii Ekonomicznej w Poznaniu, Poznań 2008.

[12] Wyszomirski O., Transport miejski. Ekonomika i organizacja., Wydawnictwo Uniwersytetu Gdańskiego, Gdańsk 2008.

\section{CONCEPTS STREAMLINING MOVEMENTS OF PERSONS IN THE MULTIMODAL SYSTEM}

The main objective of the integration of individual and collective transport is to encourage travelers to travel multimodally. It involves the use of less-populated suburban area and car transport links and the city - public transport. Travel the civil in stages, using a variety of forms of movement of pedestrians and bicycle travel by public transport: metro, trams, trolleybuses, to an own car. Of particular note in this respect they deserve concepts: Park \& Ride and Bike \& Ride. Unfortunately, the results of observations conducted by the author indicate that a large group of Poles' knowledge about the concept of the integration of individual and collective transport in the city is negligible or simply the lack of knowledge. Therefore, a good idea seems to be to present and discuss solutions such as Park \& Ride Bike \& Ride, Kiss \& Ride in more detail. This article attempts to present some concepts of public transport integration and individual, which are used primarily in well-developed cities in Western Europe, i.e. Prague, Vienna, Copenhagen, and Berlin. Knowledge of the described concept is particularly important for those dealing with urban logistics and working on solutions for solving the problem of excessive congestion of transport and urban congestion. The article describes the essence of an integrated system of urban travel and more detailed discussion of the essence of the concept: Park \& Ride Bike \& Ride, Kiss \& Ride. Keywords: travel multimodal, integrated urban travel, Park \& Ride Bike \& Ride, Kiss \& Ride, urban transport.

\section{DOI: 10.7862/rz.2015.mmr.15}

Tekst złożono w redakcji: styczeń 2015

Przyjęto do druku: lipiec 2015 